Cuadernos de Historia Moderna

ISSN: 0214-4018

https://dx.doi.org/10.5209/chmo.72526

\title{
En memoria de Trevor J. Dadson
}

Por más que el desarrollo de la historiografía española en los últimos años haya podido hacer pensar a algunos que ya no necesitamos el concurso de los hispanistas foráneos en la construcción de la historia de España, ello no es cierto. Nos siguen haciendo falta la aportación de los hispanistas para conocer mejor nuestro pasado. La "mirada del otro" siempre es positiva, pero especialmente, a la luz de los complejos que nos han acompañado tradicionalmente a la hora de examinar nuestras propias señas de identidad, es bien patente que los hispanistas han contribuido y siguen contribuyendo decisivamente a deslegitimar esos complejos, y a madurar nuestra autoestima nacional.

Por ello, es muy lamentable la muerte de un hispanista extraordinario, Trevor J. Dadson, un hombre que amó a nuestro país, como pocos, desde su extraordinario conocimiento de nuestra literatura y nuestra historia. Había estudiado español y portugués en Leeds, donde fue alumno de Colin Smith, que había hecho su tesis doctoral sobre los comentaristas de Góngora. Él, por su parte, presentó su tesis doctoral en Cambridge sobre el poeta barroco Gabriel Bocángel bajo la dirección de Edward M. Wilson. Su dedicación al estudio de la literatura española barroca se acabaría consolidando tras casarse con la aragonesa María de los Ángeles Gimeno Santacruz, a la que había conocido en la Universidad de Salamanca mientras él ejercía como lector de inglés. Su trayectoria profesional no fue fácil. Fue profesor de instituto varios años hasta que consiguió un puesto en la Queen's University de Belfast, donde sería catedrático. De ahí se trasladaría en 1990 a la cátedra de Estudios Hispánicos en Birmingham, y en el año 2004 pasó a ser catedrático en la Queen Mary University de Londres. Allí fue vicerrector y se jubilaría en el 2017. Fue profesor emérito de esta universidad, correspondiente de la Real Academia de la Historia y presidió instituciones relevantes como la Asociación de Hispanistas de Gran Bretaña o la Asociación Internacional del Siglo de Oro.

Currículum académico extraordinario con una obra excepcional en la que se conjuga su pasión por la literatura (estudios fundamentales sobre el citado Bocángel, los Argensola, el conde de Salinas e incluso sobre la poesía española contemporánea) y por la historia. En este ámbito destaca su interés por los diarios de Elisabeth Holland y George Eliot, viajeros por la España del siglo XIX, su revisión de la figura de la princesa de Éboli Doña Ana de Mendoza a la que calificó agudamente de "cautiva del rey", a partir de la correspondencia del personaje, trabajando conjuntamente con la historiadora Helen Reed y por último, sus trascendentales aportaciones al conocimiento de perfiles de moriscos como los de Villarrubia de los Ojos (Ciudad Real) que le llevó a replantear todo el discurso tradicional sobre la interrelación de los cristianos viejos y los cristianos nuevos. Testimonios de esta labor revisionista sobre los moriscos fueron sus obras: Los moriscos de Villarrubia de los Ojos (Iberoamericana, 2015) y su más reciente Tolerancia y convivencia en la España de los Austrias (Cá- 
tedra, 2017). Trevor Dadson dedicó mucho tiempo de su vida a desmitificar la típica y tópica perversidad de la Éboli y a cuestionar la imagen fatalista de los moriscos como enemigos inasimilables de la fe cristiana.

Detrás de su vocación revisionista, latió en el hispanista británico el interés por la problemática de la estructura política de la monarquía de los Austrias, con bien patentes simpatías hacia la figura de Olivares. Recuerdo muchas conversaciones (algunas en Peñíscola donde tenía una casa) con él respecto al viejo problema hispánico de la confrontación de la España vertical y la España horizontal. Su gran obsesión en los últimos años en estas conversaciones era el Brexit, para él una auténtica pesadilla británica. Trevor Dadson, más allá de su extraordinario rigor en el manejo de la documentación, fue un hombre con singular proyección emocional que ponía una gran pasión en los temas que estudiaba o sobre los que reflexionaba, aunque siempre sabía matizar sus conclusiones con una especial capacidad para la ironía. Murió en Virginia (USA) donde estaba dando clases como profesor invitado. Siempre al pie del cañón. Nos costará mucho superar el vacío que nos deja.

Ricardo García Cárcel 